\title{
High IMPACt TOURISM TRAining (HITT) Programme in NepaL ${ }^{1}$
}

\author{
Jonathan Demenge ${ }^{a}$ \\ Independent Development Consultant \\ Bibek Shrestha \\ Nepal Agribusiness Innovation Centre
}

\begin{abstract}
The High Impact Tourism Training (HITT) was a Technical and Vocational Education and Training (TVET) programme implemented by the Netherlands Development Organisation (SNV). It targeted informal workers from the tourism sector, notably women and youth, unskilled and semi-skilled workers in seven countries in Sub-Saharan Africa and Asia: among them, Nepal. Through innovative solutions, the programme aimed to provide vocational training in tourism related activities to workers from the informal sector, women and youths - who usually had limited access to formal education - in order to increase their employability and income. After drawing the contours of the TVET sector and listing the main challenges to education in Nepal, the article shows how the HITT initiative chose to address them. Based on quantitative and qualitative evidence, we show that the strategy of intervention rests principally on two pillars: the introduction of active learning methods, and close collaboration with the private sector at every stage of the process, from the analysis of the sector and needs, to the design of the training, to the implementation. The article further dwells on the potentialities, limits and replicability of the HITT programme in Nepal.
\end{abstract}

Keywords: Technical Education and Vocational Training, Nepal, Tourism

\section{Introduction}

When the small team at the Netherlands Development Organisation (SNV) started the High Impact Tourism Training (HITT) programme in Nepal, they were confronted with a major challenge: training a high number of beneficiaries from the informal sector into tourism related education with a very tight budget. Through its collaborative approach and the search for quality education and innovative solutions, the HITT programme managed to turn this initial challenge into an advantage. With limited time, human capital and budget, it set the blueprint for a vocational education scheme that combined relevance, quality content, sustainability and wide coverage. The key of success relied mainly on two elements. First of all, HITT introduced innovative teaching methods that contrasted drastically with traditional methods of education used in Nepal. Second, HITT relied on a close collaboration with the private sector from the analysis, to the design, to the development and implementation of training schemes. And companies bought in. The implementation of the scheme was never smooth, but the approach, which combined pragmatism, idealism and innovation worked beyond any expectations. Because it was tailored for companies and implemented by them, the scheme became actively supported and funded by the private sector.

This article sets the contours of the Technical and Vocational Education and Training (TVET) sector in Nepal, the HITT approach and its implementation in Nepal. The authors are two exemployees of SNV who both worked for the HITT programme in Nepal. This first-hand experience has provided us with a direct grasp on internal processes, privileged access to material and therefore unique insights on HITT.

\footnotetext{
a Correspondence can be directed to: jon.demenge@gmail.com
} 


\section{Context: The TVET Sector in Nepal}

A former Shangri-La at the crossroad of the Indian sub-continent and China with a unique mix of cultures and landscapes spanning the whole range of ecosystems, Nepal continuously attracts travellers from all over the world. Because of Nepal's recent history made of civil war, political intrigues, unfinished constitution, shattered hopes and uneven development food insecurity, displaced populations, and natural disasters - including the terrible earthquakes of April and May 2015 that killed about 9,000 people, injured 22,000 others and destroyed around 300,000 houses - the country is also hub for development workers, volunteers, non-governmental organisations (NGOs), United Nations (UN) organisations and bilateral and multilateral donors.

With a population of more than 29.3 millions inhabitants and a poverty rate of $25.2 \%$ (at national poverty lines, 2010 figure, the latest available; World Bank 2018)), Nepal ranks 149 (out of 189) in terms of Human Development Index (UNDP 2018). Nepal's economy and population are highly dependent on agriculture, which accounts for more than a quarter of its Gross Domestic Product (GDP) and provides a livelihood for more than $70 \%$ of the population. Industrial activity is mostly limited to the processing of agricultural products. Nepal's labour force counts 16.8 millions people. With an estimated 3 millions Nepalese living and working abroad (mainly in South Asia, South East Asia and the Gulf Countries), the population depends heavily on remittances, which officially amount to as much as $30 \%$ of its GDP (CIA 2018), and possibly more. Remittances account for a large share of household's incomes, with increasingly positive impacts on health, education and possibly fertility rates (Glennie 2012).

In 2010 the number of new entrants on the job market was estimated at around 525,000, and increasing, for a workforce of roughly 12 millions (UNCTAD 2013, p. 182). Among them, 30,000 graduate from TVET annually (Lamichhane 2013, p.14). However, the basic education and TVET sectors are far from providing for the needs of these new entrants, and a large proportion of them enter the job market without any form of diploma. Youth unemployment rate is $8.8 \%$, while a large proportion of youths is underemployed. The rates of unemployment among the educated youths is even higher, since "government literature reveal that employment of "skills training" graduates is between $30 \%$ and $50 \%$ " depending on sectors, and among $60 \%$ on average (Asian Development Bank 2014, p.12). In general, a large proportion of the new entrants is absorbed by the informal sector, which represents 69.7 per cent of workers outside agriculture (agriculture is almost entirely informal), or 86.4 percent of the working population if all sectors are included.

In terms of education, in 2006 16\% of children had completed primary education, and only one child out of twenty passed the School Leaving Certificates (SLC), the examination at the end of 10th class (Vaux et al. 2006); in 2015 the figure was estimated to be between 10\% and 15\% in 2015 (Asian Development Bank 2015), although it varies a lot depending on caste, social status and gender (World Bank 2018). Although the mean year of schooling has increased from 3.2 years in 2014 to 4.9 years in 2018, it is still significantly lower than the world average of 8.4 years (UNDP 2018). Primary school dropout has shown a sharp decrease from $38.3 \%$ in 2014 to $26.5 \%$ in 2018. Adult literacy rate is $59.6 \%$ and $80.2 / 89.9 \%$ among youths female/male (aged 15-24) (Ibid.). Despite recent progress, low education and skill level of the workforce are often cited as one of the reasons for under and unemployment (Sharma 2013), if not for under-development at all:

Along political uncertainty, its landlocked geographic location, power shortages, a poorly developed transportation infrastructure and susceptibility to natural disaster figure the lack of skilled labour as the main impediment to economic development (CIA, n.p.)

Low education and skill levels prevent access for a wide proportion of the population to further education and training. At the same time, education is increasingly demanded in order to fulfil the economy's need for qualified workforce, and the country's aspiration for social and economic development. This is also the case of the TVET sector. 
As in 19th century Europe - where the spread of the vocational education system was linked to industrialisation - the extension of the TVET in Nepal is also driven by the need of a standardised and certified workforce. Previously, "education was always seen as the special privilege of few upper caste people of Nepal," while for the bulk of the population "people were meant to take their occupation as per their castes" (Bhandari 2013, p.32). Required skills were transferred from one generation to the other through an unorganized family-based apprenticeship training, which is seen as the oldest form of vocational training, and which still exists the country. Yet, if "vocational education, as a share of secondary education, has declined in almost every educational system in the world" (Benavot 1983, p.63), it is not the case in Nepal, where the expansion of the TVET sector is fuelled by several factors.

Historically, the introduction of a formalised TVET sector in Nepal can be dated back to the late 1930s/early 1940s, when the government established the Technical School and Cottage Industry Centre in Kathmandu and five years later schools in the fields of technical training (engineering), art, forestry and veterinary science. The opening of the country and the beginning of the "development era" at the end of the Rana period (1846-1951) increased the need for a technical workforce able to modernise the country and its economy. The Department of Cottage and Village Industries established a series of vocational training programmes which evolved into technical institutes. The Mechanical Training Centre opened in 1962, followed by the Butwal Technical Institute and the establishment of the multiple schools in the 1960s. Through the implementation of the National Education System Plan (NESP) in 1971, vocational and technical education was introduced in each secondary school, which had to provide instruction in at least one vocational subject.

Nearly two decades later, the system was sensibly modernised in an attempt to unify its structure and disaggregate it from the general education system. In 1989, the Council for the Technical Education and Vocational Training (CTEVT) was founded, under the Ministry of Education, with the objectives of developing national policies, coordinating the TVET sector, ensuring quality, and making technical and vocational education accessible to the poor. The CTEVT remains one of the most important institutions in the TVET sector in Nepal. The need of a skilled workforce to develop the country and reducing poverty became obvious to the government and development partners, who consequently gave a high priority and invested significantly in the vocational education sector in Nepal, leading to the creation of about 400 technical schools (Lamichhane, 2013). Yet, the present structure of the TVET remains rather disorganised, embodying the slightly haphazard development of the sector and at the same time exhibiting centralising and technocratic tendencies, while the TVET offer remains of variable, often low quality.

In terms of structure, the Ministry of Education is responsible for overall development of education in Nepal, including technical and vocational education. Within it, the Higher and Technical Education section is responsible for developing and implementing policy, rules and regulations. The CETVT, a national autonomous body mandated by the government is in charge of quality control, developing curricula and skill standards of various occupations and testing the skills of workers, among many other tasks. The National Skills Testing Board (NSTB) under the CTEVT is responsible for developing national occupational skill standards, conducting skills tests, and providing certification. The CTEVT also runs technical schools, colleges, institutes and training centres which provide various short and long term vocational training programmes in the fields of agriculture, engineering, health, tourism, management and computer science. The Training Institute for Technical Instruction (TITI), mandated by CTEVT and jointly governed by the ministries and the private sector, provides training to trainers, technical instructors and curriculum development specialists.

At the level of training delivery, the TVET sector in Nepal remains highly decentralised and heterogeneous, with public, private and non-for-profit organisations delivering technical and vocational training. TVET is provided through different governmental organisations under different ministries and their agencies such as the Vocational and Skills Development Training Centre (VSDTC), Cottage and Small Industry Development Board (CSIDB), and very importantly in our case the Nepal Academy for Tourism and Hotel Management (NATHM), which is responsible for hospitality, but also 
trekking occupations. TVET programmes are also offered by private and public colleges with affiliation to Nepalese and international universities, especially in the case of Hotel and Tourism Management.

Private TVET providers - mostly concentrated in urban areas - also offer various short to medium term training. With private providers targeting most particularly youths aspiring to employment abroad, the training sector is in expansion. Yet, with the exception of private providers funded through donors' programmes, most of them are not financially viable. Private sector professional organisations such as the Federation of Nepalese Chamber of Commerce and Industries (FNCCI) also offer education and training through its trade schools. Graduates of vocational skills can have their qualifications and skills tested and recognised through the National Skills Testing Board. Finally, NGOs provide short-term education and training to the poorest and most vulnerable groups with the objective of improving people's livelihoods and well-being. These programmes are often not coordinated at national level.

Major international donors and international development agencies are also active in the TVET sector through various contributions. The Swiss Development Cooperation (SDC), which has been active in the TVET sector since 1962, helped in establishing TITI and enhancing the capacity of the National Skills Testing Board (NSTB). SDC also assists the development of the TVET Fund and the reform of the CTEVT. The Employment Fund (EF) programme, also supported by SDC with co-funding from the Department of International Development (DfID) and the World Bank, is the largest TVET programme in Nepal and provides short-term market oriented skills training to youths in 54 districts. The Asian Development Bank (ADB), active in the sector since 1976 has focused its intervention, in collaboration with the Ministry of Education (MoE) and CTEVT, on improving the sector management and performance, enhancing quality and relevance of the training, developing curricula and trainers capacities, and helping deliver market oriented skill trainings through an increased involvement of the private sector in training delivery. Since 2011, the World Bank has been working on access to quality training with the MoE, CTEVT and the Ministry of Labour through the Enhanced Vocational Education and Training (EVENT) programme. The sector has also seen the involvement of international NGOs and development agencies such as Helvetas-Swiss Interco-operation, SNV, Plan Nepal, Action Aid, Practical Action as well as UN agencies such as the ILO and UNDP.

Most donors and agencies justify their investment in the TVET sector in social and economic terms. Bhandari writes that the TVET sector has the potential to "contribute to economic development" by providing "skilled human resources" and to "overcome social exclusion" (Bhandari 2013, p.30), and shows that social inclusion and equity are two essential objective pursued since the 1990s. Sharma also shows how different TVET programmes intend to contribute to poverty reduction. Beyond that, one cannot read off the association between unemployment and violent conflict. Although "there are no grounds empirically for the commonly made claims that there is a strong, automatic causal connection from unemployment, underemployment, or low productivity employment to violence and war" (Cramer 2010, p. 2) the association is often made in the literature and in development practice. Hughes for instance justifies the need for TVET in developing countries in general and in Nepal in particular by linking "the problem of the millions who do not attend school" or "attend poorly equipped schools with large classes and poorly trained teachers" to " civil wars, violence and disease" (Hughes 2005, p.260). "Building peace," he writes, "is greatly helped by a prosperous economy that depends in its turn on available workers with adaptable skills" (Hughes 2005, p.261). As the director of CTEVT Training Division puts it, besides fulfilling economic and individual aspirations "promoting technical education and vocational training would be one of the influential tools for reconciliation of the conflict victims that help generate income and employment" (Kafle 2012, p.110). The conflict-employment link is particularly present in two TVET programmes: ILO/FAO's Jobs for Peace Programme which aims to "contribute to national peace building and poverty reduction through employment and empowerment of youths" (ILO-FAO 2011, p.1), and GIZ's Support of Measures to Strengthen the Peace Process (STPP) which targets specifically Maoist ex-combatants. 
Hence, as we can see, the TVET system in Nepal is rather fragmented and weakly coordinated. "TEVT programs and policies are effected as per the interest of donors" (Acharya 2011, p.43), and are not perceived as responding to local needs. Nationally, despite the plurality of offers and high competition between providers, the system is unsatisfactory from the point of view of quantity, access and quality. This is particularly the case for poor and disadvantaged groups as competition to entry is high and costs are prohibitive in relation to people's financial means, employment prospects and incomes. As Sharma notes, "the proportion of students enrolled in the vocational, "professional" and "technical" disciplines at the university remains extremely low, particularly from the poorer segments of the population" (Sharma 2012, p.4). Sinha also points to the huge disparities in access to TVET and technical professions regionally, caste wise and gender wise (Sinha, 2012). But one of the main issues is the quality of education. Most contents are out dated, and the quality of training does not meet the market needs and is often irrelevant to the sector, and young graduates lack training opportunities, career guidance and employment support. As a result, the TVET sector falls short of responding to the needs of the economy and to people's aspirations. Therefore, it also fails to improve people's well-being and act as a tool for social ascension and economic development.

The government of Nepal has tried to address these issues through several reforms and policies in order to increase training opportunities and produce a competitive workforce the country needed. It has attempted to expand technical and vocational education based secondary education, make skills testing and certification of skills available to the informal sector, build bridges between technical education and higher education and bring TVET institutions under its umbrella. Through the TVET policy initiated in 2007 an attempt was made to put inclusion and relevancy at the centre of the TVET system in order to make it more accessible, industry-oriented and bring it in line with contemporary international practices, notably (Sharma, 2013). The School Sector Reform Plan 20092015 also provided policy directions for vocational education such as introducing basic life skills and soft skills in the curricula, and improving secondary and higher secondary level examination and certification. Finally, the TVET policy -2012 prioritized questions of inclusion and access advocated for a substantial expansion of the sector. More recently, the Nepalese government came up with School Sector Development 2016-2023 to continue its efforts to ensure equitable access to quality education for all.

If such efforts to reform, organise, modernise and expand the sector by acting on the TVET offer are commendable, some of the main issues remain. A report published by ADB in 2002 sums up: "The national TEVT system is perceived to be irrelevant, ineffective, and inefficient with weak links to labour market demands" (Acharya 2011, p.39); quite paradoxically, that a "higher rate of unemployment among graduates of TEVT than among the uneducated" is observed illustrates this sad reality. Diagnoses and recommendations as to what priorities should be differ. Some critics point to the fact that Government's focus lies in expanding the TEVT programs rather than in ensuring quality. Responding to targets set in 10-year plans, Nepal has focused on numbers while neglecting quality, while the CTEVT has provided affiliations without considering the quality of training provided: "in order to improve the present situation CTEVT should focus its programs [on] quality control rather than on the expansion of TEVT programs" (Acharya 2011, p.45). But can we afford neglecting numbers in a country in which the training sector does not manage to respond to the needs of the economy and the population is ever expanding? Another criticism is that such reforms only address part the problem, which tend to be systemic. A first issue is under-allocation of funds, since the TVET sector barely receives $1 \%$ of all funds dedicated to education. A substantial expansion of the sector that would keep up with the annual increase of the working population would also require more government funding as well as other sources of financing: private sector for instance. Second, it is difficult to make the TVET sector suit the needs of the private sector unless the latter is more involved into the conception, curricula, content, practical training and certification of TVET courses. In other words, "interaction between CTEVT and the private sector needs to be strengthened to overcome the problem of skills mismatch and make TEVT more marketable" (Acharya 2011, p.36). 
Third, the economic absorption of young trainees cannot happen unless the economic sectors and professions that are in demand are targeted by the TVET sector. In a nutshell, the TVET sector in Nepal fails to answer three basic issues: that of relevance of the training with regard to the demand, of quality of the training, as well as coverage (or quantity).

\section{The HITT Programme}

One may wonder what a new programme - with a limited budget - may add to a crowded sector such as the TVET, which has seen so many reforms and the involvement of many important donors. Obviously, a small player may not be able to influence any meaningful systemic reform of the sector; however, it may have the ability to innovate and show alternative ways. As we will see, the answer lies in its limited niche market approach, in its approach to the role of the private sector and in the introduction of innovative teaching and learning methods.

The HITT programme - High Impact Tourism Training for Jobs and Income - was a pilot project started in January 2011 simultaneously in 7 countries: Benin, Mali, Ghana, Mozambique, Vietnam, Cambodia and Nepal. The HITT programme was part of the Investing in People thematic programme funded by the European Commission during the period 2007-2013, aiming at helping EU partners' countries achieve the Millennium Development Goals. It was managed by the Netherland Development Organisation (SNV), an international development NGO founded in 1965 in the Netherlands. As it name points out, the programme focussed on training in tourism, a field in which SNV had a long experience and extensive network both county wide and worldwide, and which was identified as having a significant potential in terms of income generation and distribution.

The project was quite straightforward: identify occupations and training needs, develop training schemes and training material, train the trainers, deliver the training to end-beneficiaries and certify them, and finally evaluate the impacts of the programme. With a budget of EUR 2.5 million, the programme had to train 8000 people in three years, develop training material, and deliver institutionalised schemes that would empower the most vulnerable groups - mostly women and youths - and last beyond the duration of the intervention. In Nepal, 1000 people had to be trained, with a budget of EUR 300,000 . In this section, we describe the process of training schemes development, before presenting the schemes and the results in more details.

\section{Analysing and Developing Training Schemes with the Private Sector}

During the inception phase, the context and tourism market in the country were analysed: size, structure and market growth potential, as well as identification of the key players. The initial study paid particular attention to potential value chains, bottlenecks and opportunities related to skills development, issues of access to training for the informal workforce, the employment situation in the tourism industry, potential salaries and wages and the status of labour unions. This confirmed the potential of tourism as one of the most promising sectors for development in Nepal, and a way to reach the poor, informal workers, and spread development to rural areas throughout the value chain. In a country with few economic resources but tremendous beauty like Nepal, it is a fact that tourism contributes a significant part to people's incomes. Nationally, tourism makes up 4 percent of total GDP and the share grows every year; tourism is also a major source of foreign currency. Tourism also has a high potential for job creation: in 2011 it was estimated that travel and tourism directly supported 412,500 jobs in Nepal (Sharma 2013, p.39).

Further meetings were held with tourism professionals - hotels, restaurants, trekking agencies as well as local authorities involved in tourism promotion - in order to map out the tourism sector, its main institutional and economic players. Meanwhile, the TVET sector was analysed: its actors and providers, their strengths and weaknesses, the way the sector is regulated, curricula developed, and certification done. The whole purpose of the exercise was to map the sector and identify training 
needs and entry points for the programme, but also potential partners, within the public, private and development aid sector. It would also enable the HITT programme to develop long-term strategies for certification and sustainability of the scheme. As per the final report, "The main challenges that had to be addressed were the difficulty to fulfil the industry's needs and demands in terms of skilled employees, the limited efficiency of the training methods, the insufficient links between trainees and employment and the lack of mechanisms for self-monitoring and post-training performance tracking" (Eyraud and Annycke 2014, p.10).

The private sector also helped the team identify occupations that were highly demanded: assistant trekking guide, trekking cooks, lodge services, porters, housekeepers, hotel cooks, waiters, informations technology (IT) marketing staff, and rickshaw pullers. Among them, opportunities to reach informal workers, women and youths, were particularly considered, while two occupations were also discarded because of costs involved and barriers to entry (education) in the case of IT marketing staff, as well as technical reasons in the case of rickshaw pullers. In this latter case, training was deemed as not sufficient to have an impact on their employability and income. Another activity - focussing mainly on hygiene for the fast-food sector - was later added as suggested by the private sector, as corresponding to the needs of the moment: the Kathmandu authorities were cracking down on fast food restaurants and closing down many of them for health and hygiene reasons. Generally, all occupations were in high demand, due to the growing size and professionalization of the tourism sector, opening of new trekking routes, and request for safety and hygiene standards in the tourism and trekking sector in particular. We focus here on two of these occupations: trek leaders (or trekking guides), and hygiene training and service excellence for the fast-food sector.

The next step - still with the private sector - involved analysing further the profession, identifying existing training schemes and needs and getting key actors onboard. In most cases official training did exist. Trek leaders, for instance, had to follow a 4-week course with the Nepal Academy of Tourism and Hotel Management (NATHM), under the condition that they had acquired 2 years of experience, had a basic command of English and were recommended by an employer. Those interested in food and beverage services had to undertake a 6 months course. The entry requirement of "SLC pass", i.e. the examination sanctioning secondary education was a barrier to entry for the immense majority of youths. In Nepal, only 28 per cent of government school candidates pass their SLC exams (Bell 2015). Even for the brightest students who attend rural government schools where teachers are poorly qualified and mostly absent, and text books are maladapted and filled with mistakes, as we often encountered through our travels, passing the SLC exam is often no more than a distant dream.

One conclusion that came out of the initial research, was that most employers - especially in the trekking sector, but also in hospitality - did not really bother whether their employees had a certificate or not. As we often heard, "the quality of training is so poor that we have to train our employees ourselves". The information was also corroborated by the trainees themselves, who often complained that the content was irrelevant, the level low, students unmotivated, and that in the end they did not get much more than a paper certificate - that everyone got anyway. As a result, an informal system of training within companies had developed: trekking companies trained their best porters as assistant cooks, cooks, serdars (head porters and in charge of logistic), assistant guides, and finally guides. Similarly, budget hotels and restaurants trained young employees - often freshly arrived from rural areas of Nepal, with only limited education. These would stay for two or three years before joining higher end hotels once they had accumulated enough experience. And in both sectors, the immense majority of workers were informally employed.

Finally, the last step in the scoping study was to identify the learners' profile - gender, culture, numeracy and literacy - and their constraints (mostly seasonal or daily availability) in relation to the skills required for the occupation. Both occupations were largely male dominated. If those working in the trekking sector sometimes had good English skills, it was not the case in the food and hygiene sector. In generally, numeracy and literacy were quite low, as is often the case with workers from the 
informal sector who tend to have limited formal education, mostly through government schools. This is one of the reasons why innovative teaching methods were required.

One of the strengths of the HITT programme was the introduction of an innovative learning approach which strongly contrasted from those usually used in the country. Education methods in Nepal tend to be extremely passive and not learner-centred. Someone with a long experience in training in Nepal and in Europe likened education in Nepal to "that in the UK under the 1944 Education Act." Techniques are mostly "talk and chalk". Students would learn through repetitions. As a trekking guide told us about his training: "We listened to academics giving lectures on flora and fauna but never went out to see what they looked like; we watched somebody climb but never experienced it" or "we quietly sat in a room next to people who could not read and write nor understand English, and half of the students were asleep". The certification was a kind of formality: "everybody had the certification, irrespectively of the achievements, as long as you had paid the fee".

By comparison, the "HITT learning approach" was founded on five core elements: andragogy, i.e. the process for adult learning; acknowledge prior learning and therefore use previous experience to support the pedagogy; active learning which involves the learner in the learning process (Prince, 2004); integrated learning which focus on real work in different contexts and settings, and privileges experience; and finally, creating motivation for learning. One of the central tools to orientate the approach was the Dale's cone of learning or cone of experience, which states that six weeks after a course, students remember only $10 \%$ of what they read, $20 \%$ of what they hear, but $70 \%$ of what they say and write and $90 \%$ of what they do (Dale, 1969). Hence, teaching had to be active, privileging the experience through all sort of games, role-plays, drama, exercises, videos, among others. For each occupation, teaching material was developed so as to incorporate this approach and to fit the profile of trainers and trainees: trainers' manuals, flip charts and posters, training kits. The material for homestay operators or cooks, for instance, was largely visual and made for trainees who were sometimes illiterate. By doing so, the programme also ensured that there was no crowding out of illiterate yet competent workers. The material was also portable and used local resources, so that it could be implemented in remote areas, sometimes one or two day walk away.

Although not revolutionary, by existing standards this way of teaching was a novelty in Nepal and was extremely effective. Also, for many trainers and trainees, it was a complete revelation: "We discovered that we can learn while having fun", as one mountain leader mentioned at the end of a training. And as a the manager of one of our partners who had successfully implemented a 4 daytraining in his company mentioned: "although my trainers are exhausted, they managed to keep my 25 staff involved and alert for the whole duration of the training: this is a performance, which happened thanks to the active learning methods. This was by far the best training I have every witnessed."

Another central element was that the curricula, training content, format and material were developed jointly with the private sector, and validated by the private sector - not trainers or "technicians" but real professionals. The HITT approach consisted in asking the private sector with humility: "tell us what you need, and we will develop a scheme that will truly fits your needs." Hence directors and staff of trekking companies, hotels and restaurants identified the content of each training: what was required, what was relevant for their field, and how it should be taught. If professional standards based on best practices were incorporated and developed with professionals - including guides and trainers from the Union of International Mountain Leader Associations (UIMLA) and of the International Climbing and Mountaineering Federation (UIAA), as well as the Petzl Foundation - these standards were always assessed and validated by the private sector, based on what is relevant in the case of Nepal. Later, private companies developed and tested the training methods and material together with the HITT team. They also identified the certification standards. In short, the private sector was at the heart of everything; the end-result was a training scheme that suited their needs, that they owned, and that would produce the workforce that they required. This would have a deep positive impact on the implementation and on the financing of the trainings. 


\section{Implementing the Training Schemes}

The implementation of each training scheme differs and answered the specificities of each occupation. However, the approach privileged one basic principle: the maximum involvement of the private sector, as each training would be implemented within companies, by employees of the companies themselves, sometimes under the supervision and coaching of a HITT trainer. The principle was that of a cascading system: HITT master trainers would train employees to become trainers within their company; these would train the company's employees and end-beneficiaries. In a way, the HITT programme built on the existing practise of in-company training, but it standardised it and professionalised it, equipping in-company trainers with training skills and materials.

For Service Excellence and Hygiene, the master trainers trained two staffs from each fast-food restaurant - generally the owner or manager and head cook - as in-house-trainers. These would later train up to eight other employees or would be employees in their restaurants. Similarly for trek leaders, master trainers would train in-company trainers selected by their company based on their experience and aptitudes to train. Those then delivered the training to their companies. Initially, master trainers would coach, supervise and monitoring the training and monitored the training to ensure quality, before phasing out once quality had been reached.

For trek leaders, each company applying for the HITT training scheme would pass an agreement that would be formalised in a contract with SNV. SNV would train some of their employees as trainers; for each employee trained as a trainer, the company would train between 8 to 10 guides, $70 \%$ of which would be informal workers. While the costs of training of trainers were supported by HITT, the costs of the training of beneficiaries was entirely born by the company. In total, at the end of the programme, 67 trainers and 394 guides had been trained through the scheme. $A$ total of 23 companies as well as the Trekking Agencies' Association of Nepal (TAAN) and the Nepal Mountaineering Association (NMA) implemented the scheme. As far as service excellence and hygiene is concerned, more than 200 trainers were trained, and 94 training of beneficiaries (ToB) were implemented for a total of 790 beneficiaries. Hence, between the different occupations, 13 master trainers trained in the HITT approach trained 315 trainers, who delivered on the job training to employees and further beneficiaries. And since training capacities were created within companies, it is believed that more beneficiaries were trained after the end of the programme.

The main advantage was that those who trained others already knew the job, and now also knew how to pass on their knowledge. Moreover, each company would be able to tweak the training programme according to their own needs: once minimum standards were reached (mainly defined along quality and safety standards), each company was free to implement the programme they desired. Moreover, trainers trained into the HITT approach would contribute to the long-term training capacity of the company, while trained beneficiaries would be directly employable by the company without further training.

\section{Results, Lessons Learnt and Replicability}

In many ways, the results went far beyond expectations and targets. By the end of the programme, 1842 beneficiaries had been trained in five different occupations, out of a target of 1000 , as measured by the monitoring system put in place. And it is likely that that more beneficiaries were trained after the end of the programme, since training capacities now existed within companies. This was also confirmed by the final report which concludes that "the capacities of the local training institutions will probably have a long term impact" (Eyraud and Annycke 2014, p. 81): "training partners confirmed that the methods they have learned have changed their approach to training in general. They all expressed their readiness to continue to use them" (Ibid.). The HITT programme showed that by putting the private sector at the centre, one could implement a training system that would ensure relevance, quality and quantity. 
The level of satisfaction was quite high, among the beneficiaries as well as among company owners. TAAN's general secretary recognised after the completion of the first ToB that it was the best training that existed in Nepal. Another encouraging sign was that when the second ToB was organised, the team did not have to encourage trekking companies to get on board: it was trekking companies that called to join the scheme, sometimes pushed by their partners in Europe. TUI, the largest tour operator in the world even contributed to the programme with a donation of EUR 10,000, which paid the second ToB and the coaching of in-company training by the HITT trainers. And as the Managing Director of Mountain Monarch mentioned during the closing ceremony: "I give a great importance to the training of my guides and I make sure that every year they get the opportunity to upgrade their skills. The HITT training is by far the best quality training they have received."

A focus on targets could well have led to prioritising numbers and employability of candidates (such as experienced workers), instead of targeting the most vulnerable and poorest of the poor. It is a risk, notably in the international tourism sector, where standards and skills requirements can be quite high in comparison with the existing offer. The programme managed to target people with low level of education, as $88 \%$ had less than 12 years of schooling, and unemployed (27\%), selfemployed (6\%), students (1\%) and informal workers (60\%) represented $95 \%$ of the beneficiaries. Also, a sizeable proportion consisted of women (22\%) and youths (67\%); the extremely poor (less than US Dollars 1.25 a day) made $39 \%$ of the total. The project also tried to collect information on incomes, but the data was unreliable due to the irregularity in revenues of beneficiaries and inability to estimate individual benefits. Yet, $91 \%$ of beneficiaries mentioned that they had observed an improvement in their income three to six months after the training. In the Service Excellence and Hygiene occupation, some restaurants that had been closed down by the authorities reopened after following the HITT training. The programme also received official recognition and media attention.

To some extent, the HITT programme was supported by external events and by the expansion of the sector: the opening of new routes, trekkers and trekking companies asking for increased security due to a series of unfortunate events, or the national authority cracking down on unhygienic practices in restaurants. The programme was carried by companies need for professionalization of training. And the low budget forced the HITT programme to find innovative solutions - like a high reliance on the private sector - which played in the advantage of the programme and made it demand driven. At the same time, the low budget also sometimes prevented the programme to recruit experienced but expensive consultants. The HITT team often had to engage with curriculum and material development, leading to over-charging the capacities of the team. On the upside, this situation led to the involvement of consultants who were deeply passionate and morally connected to the cause, to mountaineering and to Nepal.

In spite of these achievements, one may wonder what remains from the programme, what it was able to achieve on a larger scale, and how sustainable the scheme was. The answer depends on occupations. Overall, the programme has managed to train trainers that are embedded within companies and can deliver the training on a per need basis. Also, HITT developed an approach and numerous tools and material for the TVET sector, making it operational and reproducible. The programme has produced methodological manuals on the general approach (SNV, 2014a), the preparation of the activities (SNV, 2014b) and the learning process (SNV, 2014c) as well as numerous manuals which that are valuable resources for further TVET development projects, not only in the tourism sector. The HITT programme was a laboratory for the initial approach, and the whole duration of the programme has enabled its fine-tuning, and the results show that the approach was highly successful... although sometimes on a limited scale.

If the adoption of hygiene standards by a national authority (DFTQC) ensured the spread and generalisation of the HITT training scheme, the results regarding trek leaders should be put into perspective. It was believed that the NMA would endorse the scheme and make it the official trek leaders training scheme in Nepal; that the NMA would go on certifying trainers and trekking guided that would be trained by private companies; that it would go on managing the logbooks; and that this system would enable training enough trek leaders to satisfy the demand, and hence would created 
a critical mass of trek leaders trained through the HITT approach. This failed for three main reasons. First, the NMA never really took their assessment role seriously and never adopted the decentralised system of training that was offered to them. Instead, the NMA kept on training a handful of trek leaders a year ( 20 to 25 , when the needs are in the range of 1,500 a year to keep up with the growth of the sector and the needs for qualified guides. It also seems that the NMA tends to consider the trekking sector as a 'poor parent' in comparison to more respectable professions such as mountain guides. Third, and this is the main reason, NATHM still has a monopoly in terms of licensing trek leaders. Although providing inefficient substandard trainings and qualifications that are unsuited to the needs of the profession and of the sector, NATHM is the only organisation accredited by the government to give trek leaders licenses. As a consequence, NATHM, an organisation dealing with "tourism and hospitality management" still trains trek leaders for Nepal, at the rate of 800 per batch.

Why was NATHM, such a crucial player, not included into the list of partners of the HITT programme? With HITT's focus on quality training and on the private sector, NATHM was discarded at an early stage due its poor performance and irrelevance from the point of view of training companies. Working with NATHM, which is more competent in terms of hospitality than trekking, was also perceived as a potential threat to the credibility of the programme, HITT's key partners were not keen on working with NATHM either. Hence the decision was made to override NATHM and to offer a better alternative, get international certification through the UIAA and the UIMLA, and get the private sector, TAAN, as well as the NMA onboard. After all, the NMA had a better reputation in terms of training with its internationally certified mountain guides. This was probably a strategic mistake, and the HITT team should have known that one could not develop a sustainable mountain leaders training scheme in Nepal without first getting NATHM onboard. And in fact, the UIAA, TAAN and the NMA who are still working on the development of an internationally recognised certification for Nepalese trek leaders have since decided to include NATHM trek leader training as the entry point for trekking and mountaineering careers.

Was taking NATHM onboard an option? Perhaps, but the fact is that working with institutional partners and obtaining systemic changes takes time; and an NGO and a three-year programme are poorly equipped for this task. HITT did experience it in the beginning, when it attempted to reform the way CTEVT designed curricula by putting the private sector at the centre. Designing curricula was perceived as the prerogative of technicians, of the government, and not of the private sector; and this was not going to change. Organisations that benefit from the unconditional support of the government and of a monopoly over the certification of a profession or designing curricula have very little incentive to change the way they are working, especially if it means losing some of their key prerogatives (and the income that comes with it). Working with institutional partners takes time and necessitates making compromises. This is probably the reason why the idea of having a steering committee for HITT Nepal was abandoned from the very beginning. As the final evaluation puts it "the timeframe of the project was too tight for such complex and numerous activities and objectives" (Eyraud and Annycke 2014, p.9). By opposition, HITT was pragmatic and reactive, it would make alliances, and it would inform institutional partners rather than work with them. HITT's best bet was to show how well things could work and this is what it did; but that did not always lead to the idea being institutionalised or up scaled. In some cases, as in the hygiene and service excellence scheme it did; in other cases such as trek leaders, the scheme is there ready to be taken to the next level.

\section{Conclusions}

The HITT programme did show some results, and its most important contribution is to show that the system based on the involvement of the private sector does work. Hence, it offers solutions to some of the crucial issues encountered by the TVET sector, as identified in the first part of this article. First, it ensures relevance of the training, since professions and training content are identified by the private sector, and companies only train professions and skills that are in need. Second, the system also ensures training quality, since the content is developed by or with the private sector. Third, 
the system enables training on a large scale, since companies and their trainers act as multipliers, training far more people than could a training institute. The system also has multiple benefits for private companies, since it enables them to adapt training schemes to their needs, to produce readily employable staff, and to have training competencies within the company, that can be mobilised whenever required. Because of these advantages, companies are ready to support the system and finance it, as companies did pay to train HITT's end beneficiaries. Hence, the private sector is also a potential source of financing for the TVET, as long as it suits its needs.

The system also managed to increases the employability of trainees, and therefore their income and perspectives for personal and professional development. To some extent it did reach the poor, vulnerable individuals, weakly educated and youths. Beyond the introduction of new training techniques, HITT carried one single message: the private sector must be put at the centre of the TVET sector. This is a formula that has been successful elsewhere, but lacks in nearly every country in South Asia (Asian Development Bank, 2014).

However, the case of the HITT programme in Nepal also showed that an NGO with a small programme is also poorly suited to dialogue with and influence state institutions. Similarly to a small ship manoeuvring through a difficult channel made of high sands, see walls and strong currents, it can skilfully manoeuvre within the institutional framework, using winds and currents, or temporarily rowing harder to adjust its trajectory; but it cannot move barriers and reform the political economy of TVET in Nepal.

On the other hand, along with its partners, the HITT programme has contributed to show what is possible. A navigation map has been drawn, several captains and helmsmen have been trained, and lighthouses have been built. All is in place to bring the admiral ship (the TVET sector) - and its fleet (the private sector) - at sea, help deliver efficient training schemes that lead to quality and coverage, and cruise through the needs of Nepal's economy.

\section{Notes}

${ }^{1}$ This article is an updated and edited work from Education and NGOs (2015), London: Bloomsbury Academic.

\section{References}

Acharya, T. (2011). A Study of Technical Education and Vocational Training Programs in Nepal. Kathmandu: Gefont.

Asian Development Bank (2014). Innovative Strategies in Technical and Vocational Education and Training for Accelerated Human Resource Development in South Asia. Mandaluyong City: Asian Development Bank and Australian Aid.

Bell, T. (2015). Nepal's Failed Development. Available at: http://setopati.net/opinion/3307/Nepal'sfailed-development/ [Accessed 9 May 2015].

Benavot, A. (1983). The rise and decline of vocational education. Sociology of Education, 56 (2), pp.63-76.

Bhandari, U. (2013). Technical vocational education and training development and social inclusion in Nepal. Technical and Vocational Education and Training Development Journal, 1(13), pp.30-36.

CIA (2018), The World Factbook. Available at: https://www.cia.gov/library/publications/the-worldfactbook/ [Accessed 21 August 2018].

Cramer, C. (2010). Unemployment and Participation in Violence (World Development Report 2011 - Background Paper). London: World Bank.

Dale, E. (1969). Audiovisual Methods in Teaching. New York: Dryden Press.

Eyraud, F. and Annycke, P. (2014). Final external evaluation of the HITT Programme. In Investing in People Programme. Brussels: The European Union. 
Glennie, J. (2012). Remittances are not the Only Reason Young Nepalese Decide to Migrate. Available at: https://www.theguardian.com/global-development/poverty-matters/2012/jul/05/moneynot-only-motivation-nepalese-migrants [Accessed 9 May 2015].

Hughes, P. (2005). Why access to TVET for all is essential if Education for All is to be achieved, PROSPECTS, 35(3), pp. 253-267.

ILO-FAO (2011). Jobs for Peace Programme - Youth Employment and Peace Building : Fact Sheet. In United Nations Peace Fund for Nepal, Kathmandu: International Labour Organisation - Food and Agriculture Organisation.

Kafle, J.N. (2012). Vocational education, social participation and livelihoods in the post conflict situation of Nepal, TVET Development Journal, 1(12), pp. 108-111.

Lamichhane, R. H. (2013). Strategic directions for CTEVT for skilling Nepal, Technical and Vocational Education and Training Development Journal, 1(13), pp. 14-22.

Prince, M. (2004). Does active learning work? A review of the research. Journal of Engineering Education, 93(3), pp. 223-231.

Sharma, T. N. (2012). Connecting TEVT with local economic trends. TVET Development Journal, $1(12)$, pp. 1-12.

Sharma, T. N. (2013), Connecting TEVT withlLocal economic trends. TVET Development Journal, $1(13)$, pp.37-50.

Sinha, R. S. (2012). TVET: Reaching to unreached. TVET Development Journal. 1(12), pp. 13-19.

SNV (2014a). THE HIT APPROACH: An Effective Market-Led and Practical Approach to Skills Development. The Hague: SNV - The European Union - The HITT Programme.

SNV (2014b). Inception Analysis Guidelines. The Hague: SNV - The European Union - The HITT Programme.

SNV (2014c). The HIT Curriculum Development and Learning Guidelines. The Hague: SNV - The European Union - The HITT Programme.

UNCTAD (2013). The Least Developed Countries Report 2013: Growth with Employment for Inclusive and Sustainable Development New York and Geneva: United Nations Conference on Trade and Development.

UNDP (2014). Human Development Indicators and Thematic Tables. Available at: http://hdr.undp. org/en/data [Accessed 27 July 2014].

UNDP (2018). Human Development Indices and Indicator: 2018 Indicators Updates. New York: United Nations Development Programme.

Vaux, T., Smith, A., and Subba, S. (2006). Education for All - Nepal: Review from a Conflict Perspective. London: International Alert.

World Bank (2018). Country Profile. Available at: http://databank.worldbank.org/data/reports. aspx?source=2\&country=NPL (Accessed: 22 August 2018)

World Bank (2018). Nepal Systematic Country Diagnostic. Washington: World Bank Group. 
